\title{
A Current View on Recurrent Laryngeal Nerve Injury in Total Thyroidectomy
}

\author{
Lucian ALECU ${ }^{1}$, Iulian SLAVU' ${ }^{1}$, Adrian TULIN', Vlad BRAGA, Bogdan SOCEA², Cornelia NITIPIR ${ }^{3}$
}

\begin{abstract}
Introduction: Recurrent laryngeal nerve damage during total thyroidectomy was, is, and probably will be in the near future the Achilles' heel of total thyroidectomy. Material and method: To perform the research we used the PubMed database. The questions were conceived to respect the PICOS guidelines. The PRISMA checklist was used to filter the results. The search was structured following the words: „recurrent laryngeal nerve injury" AND "total thyroidectomy". Results: A total of 60 papers were identified. We excluded 12 papers as they were duplicates. From the 48 papers left, another 4 could not be obtained. Another 3 papers from the 44 left were excluded due to the fact they were not written in English. One paper was excluded as the subject did not follow our research purpose. 40 papers were left for analysis and discussion. Conclusion: To prevent recurrent laryngeal nerve lesions, at the moment in the literature there is no consensus. Unintentional injury to the recurrent laryngeal nerve is predictable but not an avertible situation thus bilateral lesions still represent a dramatic situation across the world for the patients and the operating surgeon.
\end{abstract}

Keywords: thyroid, recurrent laryngeal nerve, surgery.

\section{Rezumat}

Introducere: Afectarea nervului laringian recurent în timpul tiroidectomiei totale a fost, este și probabil va fi în viitorul apropiat călcâiul lui Ahile al tiroidectomiei totale. Material și metodă: Pentru efectuarea cercetării am folosit baza de date PubMed. Întrebările au fost concepute pentru a respecta criteriile PICOS. Lista de verificare PRISMA a fost utilizată pentru a filtra rezultatele. Căutarea a fost structurată urmând cuvintele: „leziuni iatrogene de nerv laringeu recurent" ȘI „tiroidectomie totală”. Rezultate: Au fost identificate un total de 60 de lucrări. Am exclus 12 documente, deoarece acestea erau duplicate. Din cele 48 de articole rămase, alte 4 nu au putut fi obținute. Alte 3 lucrări din cele 44 de persoane rămase au fost excluse din cauza faptului că nu au fost redactate în limba engleză. O lucrare a fost exclusă, deoarece subiectul nu a urmărit scopul nostru de cercetare. 40 de lucrări au fost pastrate pentru analiză și discuție. Concluzie: Pentru a preveni leziunile nervului laringeu recurent, în prezent în literatura de specialitate nu există consens. Leziunea neintenționată a nervului laringian recurent este previzibilă, dar nu o situație evitabilă complet, astfel încât leziunile bilaterale reprezintă încă o situație dramatică în întreaga lume atât pentru pacienți cât și pentru medicul chirurg.

Cuvinte cheie: tiroidă, nerv laringian recurent, chirurgie.

${ }^{1}$ Clinic of General Surgery, „Agrippa Ionescu” Emergency Clinical Hospital, Bucharest, Romania

2 „Sf. Pantelimon" Emergency Clinical Hospital, Bucharest, Romania

${ }^{3}$ Elias Emergency Clinical Hospital, Bucharest, Romania
Corresponding author:

Slavu Iulian, General Surgery Clinic, Emergency Clinical Hospital,

Agrippa Ionescu", Bucharest, Romania.

E-mail: iulian.slavu@yahoo.com 


\section{INTRODUCTION}

Paresis or paralysis of the vocal cords due to surgical lesion of the recurrent laryngeal represents the Achile's heal in thyroid surgery and despite the technological advances, it has not experienced a reduction in incidence. Although progress has been made in the prevention of nerve damage, however, its proportion varies between $1.5-14 \%$. This lesion is frequently one-sided and temporary, but cases can occur when it is bilateral and permanent.

Over the past 25 years, total thyroidectomy has replaced subtotal thyroidectomy when one has to manage a patient with benign bilateral multinodular goiter, Graves' disease, and patients with thyroid cancer. The operative technique that has been adapted to reduce the incidence of recurrent laryngeal nerve lesions was the transition from "side dissection" of the thyroid gland to „capsular dissection”. Mechanisms of lesion include integral or limited sectioning, nerve stretching, contusion, crushing, thermic lesion, misplaced ligation, or ischemia ${ }^{2,3}$. In the case of unilateral lesions, the patient's voice is bitonal due to the fact that the vocal cords do not have complete median movements. Dysphonia begins with the $2^{\text {nd }}$ to $5^{\text {th }}$-day post-operatively and is usually due to local edema, while nerve traction, injury, and damage to the axons can lead to dysphonia that can last 6 months. Voice modifications that continue 6 months after surgery are frequently permanent ${ }^{4}$. Bilateral lesions are serious, as both of the cords can move in a median or paramedian position and produce suffocation so an emergency tracheostomy is required. Accidental complete sectioning of the recurrent laryngeal nerve is produced frequently in the vicinity of the first 2 tracheal rings as this is the place where the nerve is closely located in the vicinity thyroid lobes in the area of Berry's ligament where dissection of the thyroid gland is normally performed ${ }^{5,6}$.

\section{MATERIAL AND METHOD}

To perform the research we used the PubMed database. The questions were conceived to respect the PICOS guidelines. The PRISMA checklist was used to filter the results. The search was structured following the words: „recurrent laryngeal nerve injury” AND „total thyroidectomy". Only papers written in English were selected. The search encompassed the following period: 01.01.1991-01.12.2020.

\section{RESULTS}

A total of 60 papers were identified. We excluded 12 papers as they were duplicates. From the 48 papers left, another 4 could not be obtained. Another 3 papers from the 44 left were excluded due to the fact they were not written in English. One paper was excluded as the subject did not follow our research purpose. 40 papers were left for analysis and discussion.

\section{DISCUSSION}

Identification of the recurrent laryngeal nerve during dissection of the thyroid gland is the gold standard to avoid damage ${ }^{7}$. However, finding the intraoperative nerve is not always easy and can even be difficult in some cases (e.g. bulky multinodular goiter or reintervention surgery) ${ }^{7}$.

The difficulty in identifying the recurrent laryngeal nerve also lies in the great anatomical variability of its position as sometimes it can have an early division of the branches before it comes into contact with the thyroid gland ${ }^{8}$.

Also very important to mention is that the paresis of the vocal cord can occur without clear intraoperative macroscopic damage of the nerve (e.g. direct section), but only by stretching during traction and dissection of the thyroid gland at a significant distance from the nerve. This incident has been and is intensively reported and discussed in the medical literature thus trying to reduce the frequency. Permanent lesions are documented with an incidence of $0.5 \%$ to $14 \%$ of patients, while transient lesions are observed between $1 \%$ and $30 \%$ depending on different studies and the strictness of postoperative otolaryngological controls $9,10,11,12,13$.

\section{Total thyroidectomy: when?}

Subtotal thyroidectomy represents the mainstay surgical treatment for multinodular goiter. Acceptance of total thyroidectomy as a standard of treatment for nodular goiter is due to concerns related to subtotal thyroidectomy and hemithyroidectomy. These concerns are related to the possibility of recurrence of the disease (development of nodules on the remaining thyroid tissue) that often occurs many years after the initial operation, this being confirmed in a significant number of patients ${ }^{14}$. The safety of total thyroidectomy and the low rate of complications was demonstrated by studies on important volumes of patients ${ }^{15}$. It is the 
current elective intervention in all treatment guidelines for thyroid cancer or lesions with malignant potential ${ }^{16}$. The advantages of removing the entire thyroid tissue include the elimination of the tumor, incidence reduction of local recurrences, and facilitation of postoperative iodine treatment, and improving the pursuit of thyroglobulin values ${ }^{17}$.

Also, the identification of a relatively high percentage of incidental neoplasms after incomplete thyroidectomy for pathologies considered benign is another argument to opt for total thyroidectomy. The presence of these cancers can reach up to $22 \%{ }^{15-17}$. Menegaux et al. assert mentions that in the cases studied he identified an incidence of neoplasia disease in $10 \%$ of the cases operated for recurrent goiter, although the first surgical intervention was addressed to a benign thyroid pathology ${ }^{16}$. Thesesalman et al. identified in $5.26 \%$ of patients papillary microcarcinoma in the remaining tissue after subtotal thyroidectomy or hemithyroidectomy above $5 \%{ }^{18}$. The increased incidence in the reoccurrence of thyroid goiter and the impossibility to further prevent hypothyroidism have decreased the legimaticy of subtotal thyroidectomy as a surgical option in the treatment of benign thyroid disease. Recurrence rates of nodular goiter after subtotal thyroidectomy or hemithyroidectomy range from $7.1 \%$ to $43 \%{ }^{18-19}$. It was also noted the failure of the prevention of nodular goiter on the remaining thyroid tissue by external administration of thyroxine has an incidence of $14.5 \%{ }^{18}$.

Also the need for chronic administration of thyroid substitutive treatment despite the fact that some thyroid tissue remains is necessary for $36.6-47.8 \%$ so this does not represent a reason to practice subtotal thyroidectomy or hemithyroidectomy ${ }^{20}$.

Recently, an important study published by Tekin et al. demonstrated that the level of Ki-67 profiling marker in the remaining thyroid tissue after subtotal/total thyroidectomy is significantly higher than in normal thyroid tissue ${ }^{21}$. Thus the high levels of Ki-67 reflect high cellular mitotic activity which exposes the patient to the restoration of the nodular goiter. Thomusch et al. confirmed the fact that experienced surgeons with a good dissection technique are important factors when one removes the entire thyroid gland ${ }^{22}$. Surgical reintervention for recurrent benign thyroid disease is associated with increased morbidity when preceded by an initial subtotal thyroidectomy. Associated high levels of malignant recurrence and increased frequency of permanent lesions of recurrent laryngeal nerve and rates of hypoparathyroidism observed at reintervention require the abandonment of this procedure in favor of total thyroidectomy.

Total thyroidectomy is considered an optimal treatment in polynodular goiter due to its frequency of multicentre and bilarity according to ATA guidelines ${ }^{23-26}$.

An option to identify the recurrent laryngeal nerve is represented by a neurolocation device but recent international guides do not recommend it routinely, only in select cases since a significant reduction in the number of lesions is not obtained ${ }^{27}$.

Several articles evaluated in a systematic review also showed that the use of systemic neuromonitoring in all patients did not decrease the risk of recurrent laryngeal nerve injury ${ }^{28}$.

Capsular dissection, visual identification of the nerve may reduce the definitive rate of lesions but unfortunately, they do not prevent paralysis of the vocal cords in a patient at risk ${ }^{29,30}$.

Most frequent recurrent laryngeal nerve lesions are not identified during the surgical intervention. The main causes are: sectioning, crushing, elongation, electric-coagulation, ligation, and ischemia due to local devascularization. Due to the factors mentioned previously, although intraoperatively the macroscopic integrity of the nerve is observed, one cannot make an assumption of the cause of a postoperative clinical manifestation due to a recurrent laryngeal nerve lesion.

\section{Anatomy}

The recurrent laryngeal nerve contains both motor and sensory fiber and has its origin in the vagus nerve in the thoracic region. On the right side, the recurrent laryngeal nerve has a superficial trajectory and sits on the lateral esophageal margin. Due to this anatomy, it is considered at an increased risk of injury when compared to the left nerve. The left the recurrent laryngeal nerve has a trajectory around the aorta and is located at the level of the neck in the tracheoesophageal ditch thus making it more protected in the case of injury. The nerves penetrate the cricopharyngeal membrane to innervate the laryngeal muscles as a single strand or as multiple divisions as many as 5 .

Their anatomical variants contribute to this increased incidence of damage as mentioned previously. The early extra laryngeal division into multiple branches of the recurrent laryngeal nerve represents the usual anatomical variation ${ }^{31,32}$. 
In general, anterior extra laryngeal ramifications are motory fibers that can sometimes be elongated during the dissection of Berry's ligament that must be severed before the thyroid gland is removed. The distortion and elongation of the nerve, caused by a large thyroid goiter are considered another important risk condition that favors damage and paralysis of the recurrent laryngeal nerve.

Also, the very high variability of the space-relation between the lower thyroid artery that needs to be resected and the recurrent laryngeal nerve that can be located posterior, anterior, or between its ramifications increases the complexity of dissection, makes hemostasis difficult, and simultaneously increases the risk of nerve damage due to poor visualization ${ }^{33}$.

Another rare anatomical variant with an incidence below $0.3 \%$ is the non-recurrent laryngeal nerve, more commonly observed on the right. There are 2 types of abnormalities classified as type I in which the non-recurrent laryngeal nerve emerges from the vagus nerve above the junction of the laryngotracheal and descends to the larynx thus tacking the aspect of a branch of the superior thyroid artery and type II where the nerve originates also from the vagus but under the laryngotracheal junction and describes a parallel route with the lower thyroid artery again mimicking a branch of it ${ }^{34}$.

\section{Situations at risk}

Several pathologies of the thyroid gland are known and demonstrated that produce a significant increase in the risk of damage to the recurrent laryngeal nerve during thyroidectomy. Of these can be listed: Thyroid cancer which by the invasion of neighboring structures and tissue retraction and in some cases, the nerve itself, increases the risk of intraoperative up to 8 times, in comparison to benign pathologies ${ }^{35,36,37}$.

\section{Mechanism of injury}

Damage to the recurrent laryngeal nerve during thyroidectomy is significantly more common when one identifies and visualizes an intact nerve at the end of the surgical intervention ${ }^{38}$.

There are several mechanisms considered responsible for these lesions without macroscopic expression.
First, during the ligation and dissection of the lower thyroid artery, nerve traction can occur especially if the artery bifurcates superior in the vicinity of the Berry ligament.

In fact, during the elongation of the ligament to mobilize the thyroid gland, it is possible that the anterior branch of the recurrent laryngeal nerve is sectioned together with it ${ }^{39}$. Furthermore, a suture knot placed close to the nerve can induce a process of local fibrosis that over time translates or even destroys the nerve through compression and ischemia although intraoperatively it has been intact. During thyroidectomy, the thyroid is mobilized and rotated medially (mandatory maneuver, explicitly described in the techniques of dissection and resection of the thyroid gland). This rotation can produce an unnoticed stretch of the recurrent laryngeal nerve if it is adherent or it mobilizes simultaneously with the Berry ligament ${ }^{40}$.

These types of indirect lesions are partitioned into 2 categories: type 1 , due to direct nerve damage by elongation of the Berry ligament superior, and type 2, due to downward traction on the gland during its mobilization which can also stretch and damage the recurrent laryngeal nerve ${ }^{40}$.

\section{CONCLUSION}

To prevent recurrent laryngeal nerve lesions, at the moment in the literature there is no consensus ${ }^{41}$. Iatrogenic injury to the recurrent laryngeal nerve is a predictable but not avertible situation and sadly, bilateral paralysis is still a tragic clinical condition that takes a heavy toll both on the patient and the surgeon ${ }^{42,43,44}$.

Compliance with ethics requirements: The authors declare no conflict of interest regarding this article. The authors declare that all the procedures and experiments of this study respect the ethical standards in the Helsinki Declaration of 1975, as revised in 2008(5), as well as the national law. Informed consent was obtained from all the patients included in the study. 


\section{References}

1. Delbridge L. Total thyroidectomy: the evolution of surgical technique. ANZ J Surg 2003. Sep;73(9):761-768 10.1046/j.14452197.2003.02756.x

2. Steurer M, Passler C, Denk DM, Schneider B, Niederle B, Bigenzahn W. Advantages of recurrent laryngeal nerve identification in thyroidectomy and parathyroidectomy and the importance of preoperative and postoperative laryngoscopic examination in more than 1000 nerves at risk. Laryngoscope 2002. Jan;112(1):124133 10.1097/00005537-200201000-00022

3. Rice DH, Cone-Wesson B. Intraoperative recurrent laryngeal nerve monitoring. Otolaryngol Head Neck Surg 1991. Sep;105(3):372-375 [PubMed] [Google Scholar]

4. Eisele DW. Intraoperative electrophysiologic monitoring of the recurrent laryngeal nerve. Laryngoscope 1996. Apr;106(4):443449 10.1097/00005537-199604000-00010 [PubMed]

5. Dimov RS, Doikov IJ, Mitov FS, Deenichin GP, Yovchev IJ. Intraoperative identification of recurrent laryngeal nerves in thyroid surgery by electrical stimulation. Folia Med (Plovdiv) 2001:43(4):10-13

6. Marcus B, Edwards B, Yoo S, Byrne A, Gupta A, Kandrevas J, et al. Recurrent laryngeal nerve monitoring in thyroid and parathyroid surgery: the University of Michigan experience. Laryngoscope 2003. Feb;113(2):356-361 10.1097/00005537200302000-00028

7. Advantages of recurrent laryngeal nerve identification in thyroidectomy and parathyroidectomy and the importance of preoperative and postoperative laryngoscopic examination in more than 1000 nerves at risk. Steurer M, Passler C, Denk DM, Schneider B, Niederle B, Bigenzahn W Laryngoscope. 2002 Jan; 112(1):124-33.

8. Nonrecurrent laryngeal nerves: anatomic considerations during thyroid and parathyroid surgery.

9. Mra Z, Wax MK Am J Otolaryngol. 1999 Mar-Apr; 20(2):91-5.

10. Rosato L, Avenia N, Bernante P, et al. Complications of thyroid surgery: analysis of a multicentric study on 14,934 patients operated on in Italy over 5 years. World J Surg 2004;28:271-6. [PubMed] [Google Scholar]

11. 11.Bergenfelz A, Jansson S, Kristoffersson A, et al. Complications to thyroid surgery: results as reported in a database from a multicenter audit comprising 3,660 patients. Langenbecks Arch Surg 2008;393:667-73. [PubMed] [Google Scholar]

12. Jeannon J-P, Orabi AA, Bruch GA, et al. Diagnosis of recurrent laryngeal nerve palsy after thyroidectomy: a systematic review. Int J Clin Pract 2009;63:624-9. [PubMed] [Google Scholar]

13. Joliat GR, Guarnero V, Demartines N, Schweizer V, Matter M. Recurrent laryngeal nerve injury after thyroid and parathyroid surgery: Incidence and postoperative evolution assessment. Medicine (Baltimore). 2017;96(17):e6674. doi:10.1097/ MD.0000000000006674.

14. S. Tezelman, I. Borucu, Y. Senyurek, F. Tunca, and T. Terzioglu, "The change in surgical practice from subtotal to near-total or total thyroidectomy in the treatment of patients with benign

15. O. H. Clark, "Total thyroidectomy. The treatment of choice for patients with differentiated thyroid cancer," Annals of Surgery, vol. 196, no. 3, pp. 361-370, 1982

16. D. S. Cooper, G. M. Doherty, B. R. Haugen et al., "Revised American thyroid association management guidelines for patients with thyroid nodules and differentiated thyroid cancer," Thyroid, vol. 19, no. 11, pp. 1167-1214, 2009
17. M. Friedman and H. Ibrahim, "Total versus subtotal thyroidectomy: arguments, approaches, and recommendations," Operative Techniques in Otolaryngology, vol. 13, no. 3, pp. 196-202, 2002.

18. P. Muller, S. Kabus, E. Robens, and F. Spelsberg, "Indications, " risks, and acceptance of total thyroidectomy for multinodular benign goiter," Surgery Today, vol. 31, no. 11, pp. 958-962, 2001.

19. A. Mishra, A. Agarwal, G. Agarwal, and S. K. Mishra, "Total thyroidectomy for benign thyroid disorders in an endemic region," World Journal of Surgery, vol. 25, no. 3, pp. 307-310, 2001

20. A. Koyuncu, H. S. Dokmetas " ,M. Turan et al., "Comparison of different thyroidectomy techniques for benign thyroid disease," Endocrine Journal, vol. 50, no. 6, pp. 723-727, 2003.

21. K. Tekin, S. Yilmaz, N. Yalc, in et al., "What would be left behind if subtotal thyroidectomy were preferred instead of total thyroidectomy?" The American Journal of Surgery, vol. 199, no. 6, pp. 765-769, 2010

22. O. Thomusch, C. Sekulla, and H. Dralle, "Is primary total thyroidectomy justified in benign multinodular goiter? Results of a prospective quality assurance study of 45 hospitals offering different levels of care," Chirurg, vol. 74, no. 5, pp. 437-443, 2003.

23. J. K. Harness, C. H. Organ Jr., and N. W. Thompson, "Operative experience of U.S. general surgery residents in thyroid and parathyroid disease," Surgery, vol. 118, no. 6, pp. 1063-1070, 1995.

24. M. Barczynski, A. Konturek, A. Hubalewska-Dydejczyk, F. Golkowski, S. Cichon, and W. Nowak, "Five-year follow-up' of a randomized clinical trial of total thyroidectomy versus dunhill operation versus bilateral subtotal thyroidectomy for multinodular nontoxic goiter," World Journal of Surgery, vol. 34, no. 6, pp. 1203-1213, 2010.

25. T. Y. Farrag, N. Agrawal, S. Sheth et al., "Algorithm for safe and effective reoperative thyroid bed surgery for recurrent/ persistent papillary thyroid carcinoma," Head and Neck, vol. 29, no. 12, pp. 1069-1074, 2007.

26. D. B. Wilson, E. D. Staren, and R. A. Prinz, "Thyroid reoperations: indications and risks," The American Surgeon, vol. 64, no. 7, pp. 674-679, 1998. [7] K. E. Levin, A. H. Clark, Q. Duh, M. Demeure, A. E. Siperstein, and O. H. Clark, "Reoperative thyroid surgery," Surgery, vol. 111, no. 6, pp. 604-609, 1992.

27. Electrophysiologic recurrent laryngeal nerve monitoring during thyroid and parathyroid surgery: international standards guideline statement. Randolph GW, Dralle H, International Intraoperative Monitoring Study Group., Abdullah H, Barczynski M, Bellantone R, Brauckhoff M, Carnaille B, Cherenko S, Chiang FY, Dionigi G, Finck C, Hartl D, Kamani D, Lorenz K, Miccolli P, Mihai $R$, Miyauchi A, Orloff L, Perrier N, Poveda MD, Romanchishen A, Serpell J, Sitges-Serra A, Sloan T, Van Slycke S, Snyder S, Takami H, Volpi E, Woodson G Laryngoscope. 2011 Jan; 121 Suppl 10:S1-16.

28. Intraoperative Neuromonitoring in Thyroid Surgery: A Systematic Review. Malik R, Linos D World J Surg. 2016 Aug; 40(8):2051-8.

29. N.J. Hayward, S. Grodski, M. Yeung, W.R. Johnson, J. Serpell, Recurrent laryngeal nerve injuryin thyroid surgery: a review, ANZ J. Surg. 83 (2013) 15e21.

30. F.Y. Chiang, I.C. Lu, W.R. Kuo, K.W. Lee, N.C. Chang, C.W. Wu, The mechanism of recurrent laryngeal nerve injury during thyroid surgery: the application of intraoperative neuromonitoring, Surgery $143(2008) 743 e 749$.

31. T. Beneragama, J.W. Serpell, Extralaryngeal bifurcation of the recurrent laryngeal nerve: a common variation, ANZ J. Surg. 76 (2006) 928e931 
32. G.W. Randolph, Surgical anatomy of the recurrent laryngeal nerve, in: G.W. Randolph (Ed.), Surgery of the Thyroid and Parathyroid Glands, first ed., Saunders, Philadelphia, 2003, pp. 300e342.

33. B. Yalcin, H. Ozan, Anatomic configurations of the recurrent laryngeal nerve and inferior thyroid artery, Surg. Today 38 (2008) 478

34. A. Toniato, R. Mazzarotto, A. Piotto, P. Bernante, C. Pagetta, M.R. Pelizzo, Identification of the nonrecurrent laryngeal nerve during thyroid surgery: 20- year experience, World J. Surg. 28 (2004) 659 e661.

35. H. Dralle, C. Sekulla, J. Haerting, W. Timmermann, H.J. Neumann, E. Kruse, S. Grond, H.P. Mühlig, C. Richter, J. Voss, O. Thomusch, H. Lippert, I. Gastinger, M. Brauckhoff, O. Gimm, Risk factors of paralysis and functional outcome after recurrent laryngeal nerve monitoring in thyroid surgery, Surgery 136 (2004) 1310 e1322.

36. G. Conzo, A. Polistena, P.G. Cal_o, P. Bononi, C. Gambardella, C. Mauriello, E. Tartaglia, S. Avenia, A. Sanguinetti, F. Medas, G. de Toma, N. Avenia, Efficacy of combined treatment for anaplastic thyroid carcinoma: results of a multinstitutional retrospective analysis, Int. J. Surg. 12 (Suppl. 1) (2014) S178eS182.

37. N.J. Hayward, S. Grodski, M. Yeung, W.R. Johnson, J. Serpell, Recurrent laryngeal nerve injuryin thyroid surgery: a review, ANZ J. Surg. 83 (2013) 15e21.

38. S.N. Karamanakos, K.B. Markou, K. Panagopoulos, D. Karavias, C.E. Vagianos, C.D. Scopa, V. Fotopoulou, A. Liava, K. Vagenas, Complications and risk factors related to the extent of surgery in thyroidectomy. Results from 2043 procedures, Horm. Athens 9 (2010) 318e325.
39. S.K. Snyder, J.C. Hendricks, Intraoperative neurophysiology testing of the recurrent laryngeal nerve: plaudits and pitfalls, Surgery 138 (2005) 1183e1191.

40. G.W. Randolph, Surgery of the Thyroid and Parathyroid Glands, Saunders, Philadelphia, 2003.

41. F.H. Lahey, W.B. Hoover, Injuries to the recurrent laryngeal nerve in thyroid operations: their management and avoidance, Ann. Surg. 108 (1938) 545e562.

42. C. Ulmer, K.P. Koch, A. Seimer, V. Molnar, U. Meyding-Lamad_e, K.P. Thon, W. Lamad_e, Real-time monitoring of the recurrent laryngeal nerve: an observational clinical trial, Surgery 143 (2008) $359 \mathrm{e} 365$

43. G. Conzo, N. Avenia, G.L. Ansaldo, P.G. Cal_o, M. De Palma, C. Dobrinja, G. Docimo, C. Gambardella, M. Grasso, C.P. Lombardi, M.R. Pelizzo, A. Pezzolla, L. Pezzullo, M. Piccoli, L. Rosato, G. Siciliano, S. Spiezia, E. Tartaglia, F. Tartaglia, M. Testini, G. Troncone, G. Signoriello, Surgical treatment of thyroidfollicularneoplasms: results of a retrospectiveanalysis of a large clinicalseries, Endocrine 55 (2017) 530e538.

44. P.G. Cal_o, G. Pisano, F. Medas, J. Marcialis, L. Gordini, E. Erdas, A. Nicolosi, Total thyroidectomy without prophylactic central neck dissection in clinically node-negative papillary thyroid cancer: is it an adequate treatment? World J. Surg. Oncol. 12 (2014) 152. 